\title{
PH.D. Dissertations Completed
}

Mouldi Hadiji-Georgetown University: Balḥārith ibn KaCb: a Literary, Cultural and Historical Study.

Rafique Kehsavjee--Harvard University: The Quest for Gnosis and the Call of History: Modernization among the Ismailis of Iran.

Judith Tucker-Harvard University: Women and the Family in Egypt, $1800-$ 1860: a Study in Changing Roles and Status.

Patricia R. Dubuisson-McGill University: A History of CUman and Masquat, c. 1750-1800.

Hassan Qasim Murad-McGill University: Ethico-Religious Ideas of CUmar II.

Andrew Rippin-McGill University: The Quranic asbāb al-nuzūl Material: an Analysis of its use and Development in Exegesis.

CAli Ahmad Al-Sharc_-University of Michigan: An Analytical Study of the Adonisian Poem.

Rohn Eloul-University of Michigan: Culture Change in a Bedouin Tribe: An Ethnographic History of the "Arab Al-Hjerat, Lower Galilee, Israel, ca. AD 1790-1977.

Barbara Johnston Koch-University of Michigan: Repetition in Discourse: Cohesion and Persuasion in Arabic Argumentative Prose.

Ziona Kopelovich-University of Michigan: Modality in Modern Hebrew.

Scot Earle Smith-University of Michigan: Application of Remote Sensing Techniques to the Study of the Impacts of the Aswan High Dam.

Toshio Suzuki-University of Michigan: Land Reform, Technology, and Small-Scale Farming: The Ecology and Economy of Gilaki-Rashti Rice Cultivators, Northern Iran.

Richard W. Redding-University of Michigan: Decision Making in Subsistence Herding of Sheep and Goats in the Middle East.

Patrick Gaffney-University of Chicago: Shaykh, Khutba, and Masjid: The Role of the Local Islamic Preacher in Upper Egypt.

Marcia Hermansen-University of Chicago: Shah Wali Allah's Theory of Religion in Hujjat Allah Al-Baligha with a translation of Volume I of Hujjat Allah Al-Baligha.

Bruce Masters-University of Chicago: The Merchants of Aleppo (16301730): The Commercial and Financial Life of an Ottoman Arab City.

Michael Sells-University of Chicago: The Metaphor and Dialectic of Emanation in Plotinus, John the Scot, Meister Eckhart, and Ibn Arabi.

\section{Ph.D. Dissertations in Progress}

Jacqueline Murgida-Georgetown University: An Analysis of Learner's Competence in Modern Standard Arabic.

Sayed Omran-Georgetown University: The Grammar Tradition in Arabic: Pedagogical Effects, Reform Efforts and Proposals for Reform.

Barbara Croken-Harvard University: Medieval Islamic History.

Marisa Escribano-Harvard University: Migration and Social Change among Palestinians.

Robert Franklin-Harvard University: Foreign Workers in the Arab Gulf. Hasan Kayali-Harvard University: Arab-Ottoman Relations in the Age of Abdulhamid.

Zachary Lockman-Harvard University: Class and Nation: The Emergence of the Egyptian Workers' Movement.

Thomas Marett-Harvard University: The 'Ulama and the Faithful in Contemporary Egypt: An Anthropological Approach.

Karen Pliskin-Harvard University: The Dynamics of Semiotics: The Study of Silver Engravers and their Art in Shiraz, Iran.

Mohammed A1-Sabbah-Harvard University: Economy of Kuwait. 
Fereydoun Safizadeh-Harvard University: Migration: An Alternative Strategy in Family Decision Making in Rural Azerbryan.

Ann Sweetser-Harvard University: The Medical Practices of the Kalash Kafirs of Chitral, Pakistan.

Frank Vogel-Harvard University: Islamic Legal Structure.

Mary Ann Koury-Indiana University: Ibn 'Ata'illah: The Invocation of the Divine Name in Islam.

Zaineb Istrabadi-Indiana University: Ahmad Zarruq: The Principles of Tasawwuf.

Saleh al-Wohaibi-Indiana University: The Seven Variant Readings of the Koran.

Douglas S. Crow-MCGill University: $C_{A Q L}$ in the teaching of the Imam JaCfar al-Şãdiq (183/702-3 - 148/765); Studies in Archaic Muslim Gnosis.

Zahia R. Dajani-McGill University: Al-CAqqad's Theory of the Islamic Hero: A Study of his Biographies of Islamic Heroes in the Context of his Total Works.

Andreas D'Souza-MCGill University: The Concepts of Revelation and Prophecy as Interpreted by Modern Indian Muslims.

Faquir M. Hunzai-McGill University: The Concept of Tawhid in the Thought of Hamid al-Din AT-Kirmant (d. 412/1012).

S.S. Khusro Hussaini-McGill University: Love and Oneness in the Sufism of Gīsūdirāz.

Shigeru Kamada-McGill University: Perfection of Soul (nafs) in the Philosophy of Sadr al-Dīn al Shīrāzī.

B. Todd Lawson-McGill University: The Qur'an Commentary of the Bab (Sayyid CAlī Muhammad Shīrāzī, 1819-1850).

Hoda Lotfy-McGill University: Studies in the History of Al-Quds During the Last Decade of the Fourteenth Century A.D. - Based on the Haram Estate Inventories and Related Documents.

Derryl MacLean-McGill University: Religion and Society in Arab Sind.

Linda Northrup-McGill University: A History of the Reign of the Mamluk Sultan al-Manşur Qalà'ūn (678-689 A.H./1279-1290 A.D.).

Karon D. Salch-McGill University: Necmett in Erbakan, Nurettin Topcu, Sezai Karakoc and the Search for a New Identity in Turkey.

Norma Salem-McGill University: Islam in the Political Thought of Bourguiba.

Muhammad A. Samad-McGill University: Ibn Qutaybah's Contribution to Qur'anic Exegesis: an Analytical Study of his Ta'wīl Mushkil al-Qur'ān.

Ahmad Tahir-McGill University: Social Writing of Shaykh CUthmān b. Fudi: a Critical and Analytical Study.

\section{Appointments and Promotions}

Lisa Anderson-Assistant Professor of Government, Harvard University. Everett Rowson-Assistant Professor of Arabic, Harvard University. Uner Turgay-Associate Professor, Islamic Studies, McGill University. Donald P. Little-Director, Institute of Islamic Studies, McGill University.

Issa Boullata-Assistant Director, Institute of Islamic Studies, McGill University.

Muhammed Hallaj-Director, Institute of Arab Studies, Inc., Belmont, Massachusetts.

Manfred Wenner (Northern Illinois University)-President, the American Institute of Yemeni Studies, 1982-1984.

John G. Kennedy (UCLA)-Vice President, The American Institute for Yemeni Studies.

Howard Hallengren (New York City)-Treasurer, American Institute for Yemeni Studies. 
Caesar Farrah (University of Minnesota)-Secretary, American Institute for Yemen i Studies.

Kassim Shehim-Visiting Assistant Professor, Idaho State University, Pocatello.

Tagi Sagafi-nejad-Assistant Professor of Economics and Middle Eastern Studies, University of Texas at Austin.

James Reid-Assistant Professor of History and Religion Studies, Lehigh University.

Bruce Masters-Assistant Professor of History, Wesleyan University.

Robert M. Haddad-Sophia Smith Professor of History and of Religion and Biblical Literature, Smith College.

Cornell H. Fleischer-Assistant Professor of History, Washington University

R. Stephen Humphreys-Associate Professor, University of Wisconsin, Madison.

Hanna Batatu-First Holder of the Shaykh Sabah Al-Salem Al-Sabah Professorship of Arabic Studies, Georgetown University

John L. Esposito-Professor, Department of Religious Studies, College of the Holy Cross.

Marcia Hermansen-Department of Religious Studies, San Diego State Univ. Bruce Masters-Department of History, Wesleyan University.

Rhoads Murphey-Department of History, Columbia University.

Michael Sells-Department of Religious Studies, Stanford University.

Paul Sprachman-Assistant Librarian, Middle East Collection, Regenstein Library, University of Chicago.

Muhammad Subhi Eissa-Lecturer in Arabic, Northwestern University.

William Peachy-Instructor in Persian and Turkish in the Department of Judaic and Near Eastern Languages and Literatures, Ohio State Univ.

\section{Fellowships and Grants Awarded}

American Numismatic Society, Summer Fellow, 1982

Boyd $F$. Johnson-University of Chicago:

American Research Center in Egypt, 1982-1983

Leonard Binder [U/Chicago]: Islamic Liberalism and the Challenge of the Resurgence of Fundamentalism.

Benjamin Braude [Boston College]: Relations Between the Egyptian Vice-Regency and Central Arabia, 1840-1870.

Leonard C. Chiarelli [U/Utah]: History of Fatimid Sicily.

Carolyn B. Fluehr-Lobban [U/Pennsylvania]: A Regional Comparison of Marriage in the Sharj'a in Egypt and the Sudan.

Nancy Gallager [U/California,SB]: Socia] History of Medicine in Egypt, 1900-1980.

Sam I. Gellens [Columbia U]: Social History at the Provincial Leve]: The Culama' of Early Muslim Egypt, 800-1100, C.E.

Peter Gran [Temple/U]: Religious Culture and State Formation in Egypt, $1835-1885$.

Jerald D. Green [U/Michigan]: Mass Bureaucratic Recruitment.

Joseph J. Hobbs [U/Texas]: Environmental Change in Egypt. Attitudes and Behavior of the Eastern Desert Bedouin.

Fedwa Malti-Douglas [U/Texas]: Blindness and the Blind in Medieval Islam.

Scott L. Marcus [UCLA]: The Maqãm Tradition in Egypt: from the Performmer's Perspective. 
Shaun E. Marmon [Princeton U]: The Free and the Unfree: Domestic Slavery and Clientage in a Pre-Modern Muslim Society.

Richard C. Martin [Arizona State U]: Understanding the Qur'an in Text and Context.

Safia K. Mohsen [SUNY, Binghamton]: Class, Economy, and Woman's Employment in Egypt.

Donald M. Reid [Georgia State U]: The Role of Cairo University in the Social, Intellectual, and Political History of Modern Egypt, 1908-1958.

Paula A. Sanders [Princeton U]: The Ceremonial of the Fatimid Caliphs in Egypt, 969-1169.

Daniel M. Varisco [U/Pennsylvania]: The Arabic Astronomical Reckoning System of Lunar Stations.

Estelle J. Whelan [New York, NY]: Revitalization of Traditional Crafts in Cairo at the End of the Nineteenth Century.

Donald S. Whitcomb [U/Chicago]: Quseir and its Archaeological Environment.

Irene A. Bierman [UCLA]: The Significance of the Lam-Alif - Alif-Lam Sequence.

Fulbright-Hays Faculty Research Abroad Program 1982-83

Dale Eickelman-New York University: Work, Economy and Community in Coastal Oman.

Elaine C. Hagopian-Simmons College: Minorities as Transnational Actors in International Politics: Case Study of Lebanese Maronites.

Richard C. Martin-Arizona State University: Understanding the Qur'an in Text.

Safia K. Mohsen-SUNY, Binghamton: Class, Economy, and Women's Emp loyment in Egypt.

Jonas Prager-New York University: Inflation in Israel: Lessons for U.S. Economic Policy.

David D. Commins-University of Michigan: Syrian Salafi Thinkers in the Latter 19 th Century.

Vincent J. Cornell-UCLA: Al-Jazuli and the Jazuliyya: Ethical Leadership and Social Change in the Far Maghrib.

Joseph J. Hobbs-University of Texas: Environmental Change in Egypt: Attitudes and Behavior of the Desert Eastern Bedouin.

Boyd $F$. Johnson-University of Chicago: The Structure and Evolution of the Centralizing Administration of the Last Three Mongol Il-Khans of Iran.

Ruth E. Mandel-University of Chicago: Cultural Integration of Returning Migrants in Istanbul.

Susan E. Slymovics-U.C., Berkeley: Sirat Bani Hilal: Epic Poetry and Its Poets in Egypt.

Beatrice St. Laurent-Harvard University: Bursa: City Development from the Fourteenth through Nineteenth Centuries.

Frank E. Vogel-Harvard University: Understanding Islamic Law in Its Application: The Example of Saudi Arabia.

Fulbright Islamic Civilization Research Grantees, 1982-1983

Esin Atil-Freer Gallery of Art: Research 0bjects and Documents from the reign of Suleyman, and determine Stylistic and Iconographical Innovations of ottoman art.

Jerrold D. Green-University of Michigan: Mass Bureaucratic Recruitment and Public Policy Implementation in Egypt. 
Alexander Kaczmarczyk-Tufts University: The Evolution of Islamic Glazing Technology as Deduced from the Composition of Architectural Tiles of Cairo Monuments.

Kenneth J. Perkins-University of South Carolina: The Sudan Railways and the Development of New Communities in Early 20 th Century Sudan.

Donald M. Reid-Georgia State University: The Role of Cairo University in Egyptian National and Intellectual Life, 1908-1958.

Mark A. Tessler-University of Wisconsin: Survey Research in Arab Society.

Allan Christelow-Bayero University: Militant Traditions in Modern Times: Contemporary Islam in Algeria and Northern Nigeria, 1920-65.

Tawf ic Farah-Middle East Research Group, Inc.: Survey Research in Arab Society.

Charles L. Redman-SUNY, Binghamton: The Growth of Islamic Cities and Dynastic States during the Medieval Period in Morocco.

Harvard University Research Fellows, 1982-1983

Gunther Barthe1-Doctor of Science, Karl-Marx University, Leipzig. Ali Bakr Jad-Professor of English Literature, King Saud University, Riyadh.

Inayat Allah Baloch-Sth. Asian Institute, University of Heidelberg.

Nicholas S. Hopkins, Professor of Anthropology, The American University in Cairo.

Zvi Hershlag-Professor of Economics, Tel Aviv University.

Judith Tucker-Post-Doctoral Fellow, CMES

Hossein Ziai-University of Teheran, Post-Doctoral Fellow, CMES.

John Simon Guggenheim Memorial Fellows - 1981

Roy P. Mottahedh-Princeton University: Bureaucracy in Medieval Iran and Iraq.

Lawrence Rosen--Princeton University: The Theory and Practice of Justice in a Modern Islamic Law Court.

Denis Sinor-Indiana University: Studies in the History of Inner Asia.

\section{International Exchange of Scholars}

Alfred Ivry-Brandeis University: Islamic and Jewish Philosophy. Norton S. Ginsburg-University of Chicago: Human Geography, Israel. Frederick 0. Gearing-SUNY, Buffalo: Anthropology/Urban Ethnography, Israel.

\section{MacArthur Prize Fellowship}

Fouad Ajami-Johns Hopkins University: Middle East Affairs.

National Humanities Center Fellowship, 1982-1983

Leila Ahmed-University of Massachusetts: A Common Past: Women in Middle Eastern History.

Toshihiko Izutsu-Keio University: Studies in Islam. 
Clinton Bailey (Israel) - The Translation of Bedouin Poetry from Sinai and the Negev.

Robert D. MCChesney (NYU) - Translation of Siraj al-Tawarikh (Annals of Afghan istan, 1880-1897).

Grace M. Smith (Berkeley, Ca)-Translation of the "Divan" of Yunus Emre: Annotated Translation of the Poetry of Turkey's 14 th Century "National Poet."

Karl Stowasser (U. of Maryland)-The Story of Medieval Egypt: al-Maqrizi's Topographical History

Bernard G. Weiss (Lewiston, NY)-Translation of Al-Amidi's Questions and Answers in Islamic Jurisprudence.

\section{NEWS FROM GREAT BRITAIN}

The following information was $k$ indly supplied by Robin Bidwell, University of Cambridge; R.I. Lawless, University of Durham; J.T. Suddaby and L.P. Elwell-Sutton, University of Edinburgh; D.E.P. Jackson, University of St. Andrews.

\section{PH.D's Completed}

C.D. Holes-University of Cambridge: A Sociolinguistic Study of the Arabic-Speaking Speech-Community of Bahrain: Language Variation in Relation to Sect-Membership, Religion and Literacy.

Mahmoud Abdullah Jaffal-University of Cambridge: Arabic Philological Studies in the 4th Century AH/10th Century AD, Their Origin and Development.

Khalid Karaki-University of Cambridge: From Islamism to Arabism: A Study of the Political Ideas of Syrian Writings 1918-1952.

M.G. Mian-University of Durham: Spatial Patterns of Population Growth and Agricultural Change in the Punjab, Pakistan, 1901-72.

W.G. Rigden-University of Durham: Afar, Ethiopia: a Local Seismic Survey.

I.C. Harrison-University of Durham: Integrated Rural Development in a Case Study of Monastir Governorate Tunisia.

S.Y. Seyedna-University of Durham: A Genetic and Demographic Study of the Zoroastrians of Iran.

M.H. Whitton-University of Durham: An Analysis of Land Use and Water Use Patterns of the Esfahan Region.

A.E. Yücel-University of Durham: Turkish Migrant Workers in the Federal Republic of Germany: An Anthropological Study of Migration.

Parinaz Shahnevaz-University of Edinburgh: The Struggle for Supremacy between the Zands and the Qajars, 1193-1209/1779-1794: A Society in Transition.

Ahmad Taheri-University of Edinburgh: Zandaqa in the Early $\mathrm{C}_{\mathrm{Abb}}$ asid Period with Special Reference to Poetry.

Robert Wells-University of Edinburgh: Jalāi Āle Ahmad, Writer and Political Activist.

Bernard L.P. O'Kane-University of Edinburgh: Timurid Architecture in Khurasan.

Abdul-Rahman S. Abdullah-University of Edinburgh: Educational Theory: A Qur'ānic Outlook.

Jasim Sagbain Ali-University of Edinburgh: The Christians of the Jazíra 17-132 A.H./638-750 A.D. 